\title{
The Distribution and Promotion of Dogman (2016) in the United States
}

\section{Damiano Garofalo}

\begin{abstract}
This article will analyse the distribution and promotion strategies of Matteo Garrone's Dogman (2018) in the United States. It will reconstruct the singularity of this case study in a comparative perspective, considering both the international circulation trends of European national cinemas and the distribution of contemporary Italian films in the United States. An integrated methodology will be adopted, combining film and media industry studies, cultural studies, and the field of art and culture economics. After an analysis of the tendencies of the distribution of Italian contemporary arthouse cinema in the United States, the specific distribution strategies adopted for Dogman will be considered against the background of the financing system within which the production model of the film is embedded. Further, the role of Magnolia Pictures, the North American distributor of Garrone's film, will be inspected through the discussion of some interviews with professionals directly involved in the promotion and distribution of the film.
\end{abstract}

In this article, I will analyse the distribution and promotion strategies of Matteo Garrone's Dogman (2018) in the United States. After the premiere in competition at Cannes in 2018, the film was shown in a few international film festivals, and then theatrically distributed all over the world. It came to the US theatres in April 2019, following the paths of limited release strategies for the North American niche markets. This article will reconstruct the singularity of this case study in a comparative perspective, considering both the international circulation trends of European national cinemas and the distribution of contemporary Italian films in the United States. To achieve this, I will adopt an integrated methodology that will take into consideration film and media industry studies, cultural studies, and the economics of art and culture field. This approach aims to prove how industrial strategies intersect with the cultural repercussions of Italian cinema's circulation abroad, through a case study characterised both in terms of genre and of a strong legacy to the tradition of European arthouse cinema. As the timeframe of the research, I will take into consideration the Italian films which were produced in Italy and distributed in the United States during the last fifteen years.

The article is divided into four main sections. In the first one I will reconstruct the distribution tendencies of Italian contemporary cinema abroad, with specific references to the United States film market. I will consider the case of Garrone's films in the context of the circulation of Italian auteur cinema in the United States, taking a few other examples (such as Paolo Sorrentino and Luca Guadagnino's films) into account. In the second section, I will focus on the distribution strategies of Dogman in the United States by retracing the financing system within which the production model of the film is embedded and by discussing the role of Magnolia Pictures, which is one of the most important American film distributors specialised in both foreign and independent films. The third section of this article focuses on the promotion strategies adopted for the US market, with a specific reference to the poster design and the recut of a trailer for the 
North American audiences. In particular, I will analyse the Academy Awards campaign that was organised, and also the economic and political role of the Italian government in the promotion and distribution of the film in the United States. In the second and third sections, the article relies on interviews I made with professionals directly involved in the promotion and distribution process of the film, such as Neal Block, who is Head of Distribution and Marketing at Magnolia Pictures, and Ira Deutchman, the organiser of an initiative called Cinema made in Italy, directly supported by the Italian government. All the quantitative data present in this article come from several sources and database, such as LUMIERE (European Audiovisual Observatory), Filmitalia (Cinecittà Luce) or Box Office Mojo/IMDb Pro (Amazon Studios).

\section{Italian Cinema Abroad: The Case of Matteo Garrone}

In the last fifteen years, the Italian film industry has promoted two different trends: on the one hand, the production of a national cinema strongly targeted for the Italian market, but scarcely exportable (lowbrow); on the other hand, auteur films that produce important volumes of circulation abroad, but with little domestic success (highbrow) (O'Leary; Scaglioni). Within this complementary articulation, in the international circulation of European films we notice a clear lag of Italian cinema compared to other national cases (Holdaway and Scaglioni). Taking into consideration the volumes of circulation of European cinema in the United States over the last fifteen years, we can notice a marginality of the Italian case. In addition to a noticeable decrease of US audiences for exported Italian films, the circulation of Italian cinema in North American theatres seems to be further limited around the figures of a few authors: Luca Guadagnino, Paolo Sorrentino and Matteo Garrone. If at the beginning of the millennium European cinema (English and French, above all) was distributed in the United States around new production models that we could define as middlebrow (Higson, Concept; Waving), Italian cinema seems instead to have been crushed by old highbrow models. While the American arthouse circuits destined for independent cinema entered into a deep crisis between the 1980s and the 90s (Tudor), Italian cinema seemed unable to withstand the impact of the changes within the American film industry. With the definitive disappearance of these alternative spaces of circulation, and the consequent "dissolution" of independent cinema within the mainstream circuits (Perren), Italian cinema continued to produce art films loaded with stereotypes and legacies of the cinema of the past, albeit with a decreasing international appeal.

As mentioned above, the theatrical distribution of Italian cinema abroad appears limited, in recent years, to a series of particularly appreciated auteurs at an international level. Examining the data more closely, the same dynamic categorises the circulation of Italian cinema abroad in general: the most exportable products, unlike the top-ranked products of other European cinemas, often seem to be connected to the category of "auteur art cinema". ${ }^{1}$ We are talking mostly about auteurs who tend towards a re-actualisation of the traditional categories of European cinema already identified by Thomas Elsaesser: the authorial and national dimension; the a priori valorisation of realism; the oppositional character to Hollywood. In the wake of these porous categories, there is a need for obvious differentiation between very diverse authors. Considering the directors most successful on the international markets in the last fifteen years, we can grasp how Luca Guadagnino's films, while referring more or less explicitly to the Italian film tradition of the past, relaunch themes and characters of that cinema in a global and transnational dimension 
(Garofalo). At the same time, the films directed by Paolo Sorrentino correspond to the trend of non-blockbuster international cinema that is nevertheless distributed in mainstream circuits, while maintaining a series of distinctive traits which clearly invoke the great tradition of modern Italian cinema (Fadda and Garofalo). The films of both authors represent a process of cultural legitimation for the US spectators, that still draws from a precise idea of European national cinema-although on some occasions Guadagnino and Sorrentino shot in English with international actors.

Within this context, it could be interesting to analyse the case of the US distribution of the films directed by the third author in the ranking of international admissions after Guadagnino and Sorrentino, that is Matteo Garrone. By looking at the top twenty five most successful Italian films in the United States in the last fifteen years, Garrone is represented with four films: Gomorrah (Gomorra, 2008, \$1,579,146), Dogman (2018, \$148,225), Tale of Tales (Il racconto dei racconti, 2015, \$118,925) and Reality $(2012, \$ 95,373) .{ }^{2}$ Two of these films, Gomorrah and Tale of Tales, were distributed by IFC Films, a company owned by AMC which is specialised in the distribution of independent films, foreign films and documentaries in the United States; Reality was instead distributed in North American theatres by Oscilloscope Films, a small distribution company focused mostly on independent European cinema; finally, Dogman was distributed by Magnolia Pictures, a company that releases in the United States independent, foreign and genre titles. To sum up, all four Garrone's films were distributed in the United States by similar independent companies specialised in foreign arthouse films, but none of them was able to reach a proper mainstream circuit - even if we can consider Gomorrah as a clear exception in these trends.

The name of Garrone became popular in the United States soon after the international release of Gomorrah, which also represents (as of 2021) the fourth highest Italian revenue in the world of the last fifteen years, after Call Me by Your Name (Chiamami col tuo nome, 2017) by Luca Guadagnino, The Great Beauty (La grande bellezza, 2013) and Youth (2015) by Paolo Sorrentino. Gomorrah was released in the United States on 13 February 2009, at New York's Lincoln Plaza Cinemas and IFC Center and at Los Angeles' Laemmle Royal theatre. The theatrical release was followed by a rollout in all major markets across the country: in April 2009 its distribution peaked with fifty theatres and, by week twenty-five, it had grossed \$1.579.146 with 209.165 admissions (US and Canada). ${ }^{3}$ As already observed by Paola Brembilla, who has worked on both the distribution and the reception of the film abroad, "Gomorrah's theatrical distribution increased over its release period, arguably thanks to the constant promotion through awards and more festivals": the film gained a nomination for the Independent Spirit Awards and one at the Golden Globe for Best Foreign Film (Brembilla, "Critical Reception"; "International Circulation"). By virtue of its large theatrical circulation, we can argue that the subsequent films directed by Garrone have benefited from this success. Even though they are very different films in terms of topics covered, imagery of reference and cinematic staging and aesthetic, we can trace a red thread connecting Gomorrah with the last film in Garrone's corpus, Dogman, not only in terms of intertextual cross-references between the two films, or of their belonging to the same genre, but also in relation to the theatrical distribution strategies and the promotion of the two films in the United States. In the following sections, I will focus precisely on these two aspects. 


\section{The Distribution of Dogman in the United States}

Dogman is an international co-production between France and Italy. The film was produced in 2008 by Archimede Film, an Italian company founded in 1997 by Matteo Garrone, and Le Pacte, a French production society created in 2007 by Jean Labadie that specialises in international co-production and in theatrical distribution of foreign films in France. ${ }^{4}$ The film was also co-produced by Rai Cinema (the film production company of the Italian public service broadcasting), with the support of several institutions such as Ministero dei Beni e delle Attività Culturali e del Turismo (MiBACT), Eurimages (European Council) and the Aide aux Cinémas du Monde (Centre national du cinéma et de l'image animée) funds, and the Regions of Lazio and Campania (the two locations where the film was shot). As we can see, the production and the distribution of the film is directly supported by public funds, with the involvement of both Italian and French Governments. Moreover, we can note the participation of Canal+ (a French pay-TV network owned by Vivendi) and Ciné+ (the former CinéCinéma, a set of thematic television channels broadcasting movies) that, thanks to the collaboration with Rai Cinema, draw out the current importance of television networks in supporting the production of European national cinemas (Barra and Scaglioni). Consequently, the State and the broadcasters (public or private) investments in auteur cinema serve as a cultural legitimation within very precise and historically affirmed cultural policies. Despite the large involvement of French companies and institutions, Dogman remains a major Italian production, with a budget of just four million euros.

The international distribution of Dogman follows well-defined routes. After the premiere in competition at Cannes Film Festival on 16 May 2018, where it won the Best Actor Award with Marcello Fonte, the film was also screened at several other festivals across the world (Brussels, La Rochelle, Jerusalem, Melbourne, Sarajevo, Telluride, Toronto, Zurich, Busan and many others since mid-2019). After and during its festival itinerary, the film was sold in more than twenty countries worldwide, following the path of limited release strategies for similar niche markets made of culturally legitimated audiences. Outside the Italian market, where the film grossed $\$ 2,968,706$ from an approximate audience of 430,819 admissions, Dogman grossed over $\$ 2,111,441$ across the world. In the North-American context, after the screenings at Telluride Film Festival (31 August 2018) and Toronto International Film Festival (6 September 2018), the film was screened in a few other smaller festivals, such as the Fantastic Fest in Austin, Texas (23 September 2018), the Vancouver International Film Festival (27 September 2018), the Chicago International Film Festival (19 October 2018), the Virginia Film Festival in Charlottesville (4 November 2018), the AFI Film Festival, Los Angeles (13 November 2018), and the Gasparilla International Film Festival in Tampa Bay, Florida (23 March 2019). ${ }^{5}$ After almost a year since the Cannes premiere, on 12 April 2019 the film was finally released in US theatres. Dogman was theatrically distributed by Magnolia Pictures, which in 2010 had already organised the theatrical release of I Am Love (Io sono l'amore) by Guadagnino, the film that obtained the largest boxoffice takings of the decade for an Italian film in the US since the release of Call Me by Your Name in 2017, also by Guadagnino. While testifying to the continued presence of a number of independent agents involved in the distribution of Italian cinema in the United States-e.g., Janus Film, Criterion and Magnolia - it also represents a precise idea of European auteur cinema in the North American context. 
Magnolia Pictures is one of the most important American film distributors specialised in both foreign and independent films. The company was founded in 2001 by Bill Banowsky and Eamonn Bowles, and is a subsidiary of Mark Cuban and Todd Wagner's 2929 Entertainment. Magnolia distributes some of its films, especially foreign and genre titles, under the Magnet Releasing arm. Among its most important European movies distributed in the last decade, they released several reasonably successful Italian films following the paths of the traditional foreign film distribution in the United States (Segrave 130-31). As for other similar cases, the theatrical life of Dogman began in New York, before moving to a limited number of North American cities, trying to expand and reach ever larger audience shares. During the opening weekend (12-14 April 2019), the film was released just in three cinemas, grossing $\$ 13,013$. Magnolia choose two of the best possible theatres for a foreign language film in New York, the Film Forum downtown and the Film Society at Lincoln Centre uptown, and the New Art theatre in Los Angeles ${ }^{6}$. After that, the distribution lasted fourteen weeks, reaching a maximum of twelve theatres during the fifth programming week (10-16 May 2019). At the end of the release, the film grossed $\$ 148,225$ in total across the United States.

\section{The Promotion of Dogman in the United States}

Magnolia acquired Garrone's film after the premiere at Cannes Film Festival. Taking advantage of the presence of a film market in Cannes, the distribution team approached the sales agent to make an offer and they obtained the film rights for the United States. After this operation, Magnolia created their own materials for the promotion of the film, considering the consultation rights for the Italian producers and distributor (which was 01 Distribution, a company incorporated under the division of Rai Cinema). As the film was selected to represent Italy at the 2019 Academy Awards in the category for Best Foreign Language Film (but then did not make the shortlist of the ten preselected films), Magnolia had also to assist the standard distribution material with a specific Academy campaign. Ira Deutchman, an American producer, distributor and marketer of independent films, was involved in this process. Importantly, Deutchman organises an initiative called Cinema made in Italy, a programme funded and sponsored by Istituto Luce Cinecittà and the Italian Trade Commission, which promotes and distributes contemporary Italian films to theatres in the United States. As noted by Neal Block, who is Head of Distribution and Marketing at Magnolia Pictures:

No other government from any other territory is doing what Italy is doing to help the theatrical releases of Italian films in the US. Normally Magnolia is a pretty risk-averse company: we do not spend a lot of money on Academy campaigns because it's just a total waste of money for the most part, we would spend the bear minimum of dollars on a film pre-shortlist, just because we don't have a lot of money to spend on campaigns for any release. We prefer to save the money that we do have and use it for the theatrical off, rather than a big Academy campaign. That said, because Ira Deutchman was involved, we were able to do more ads, have more screenings and do a few events that we wouldn't have done otherwise. (Qtd. in Garofalo, "Making”)

Usually, Magnolia releases foreign language films in the US during the spring. If a movie has a good chance to get nominated, they prefer to start its release at the end of the year, to be able to 
count on a much more "aware" audience for it. This time, they decided to release Dogman in the spring, leaving just five months prior to the Academy campaign. This is because Magnolia knew that the business for the film was going to be limited. On this topic, Block observed that,

Dogman is violent, a little unpleasant, grimy and it doesn't present the kind of Italy that an American audience expects or wants to see. It's a difficult film, but we knew that we would be able to make it profitable: it was an affordable film for us, and we knew that we have enough know-how for small, foreign language films to make it work. [...] Older audiences, unfortunately, are the only audiences in the US that go to see foreign language films. (Qtd. in Garofalo, "Making")
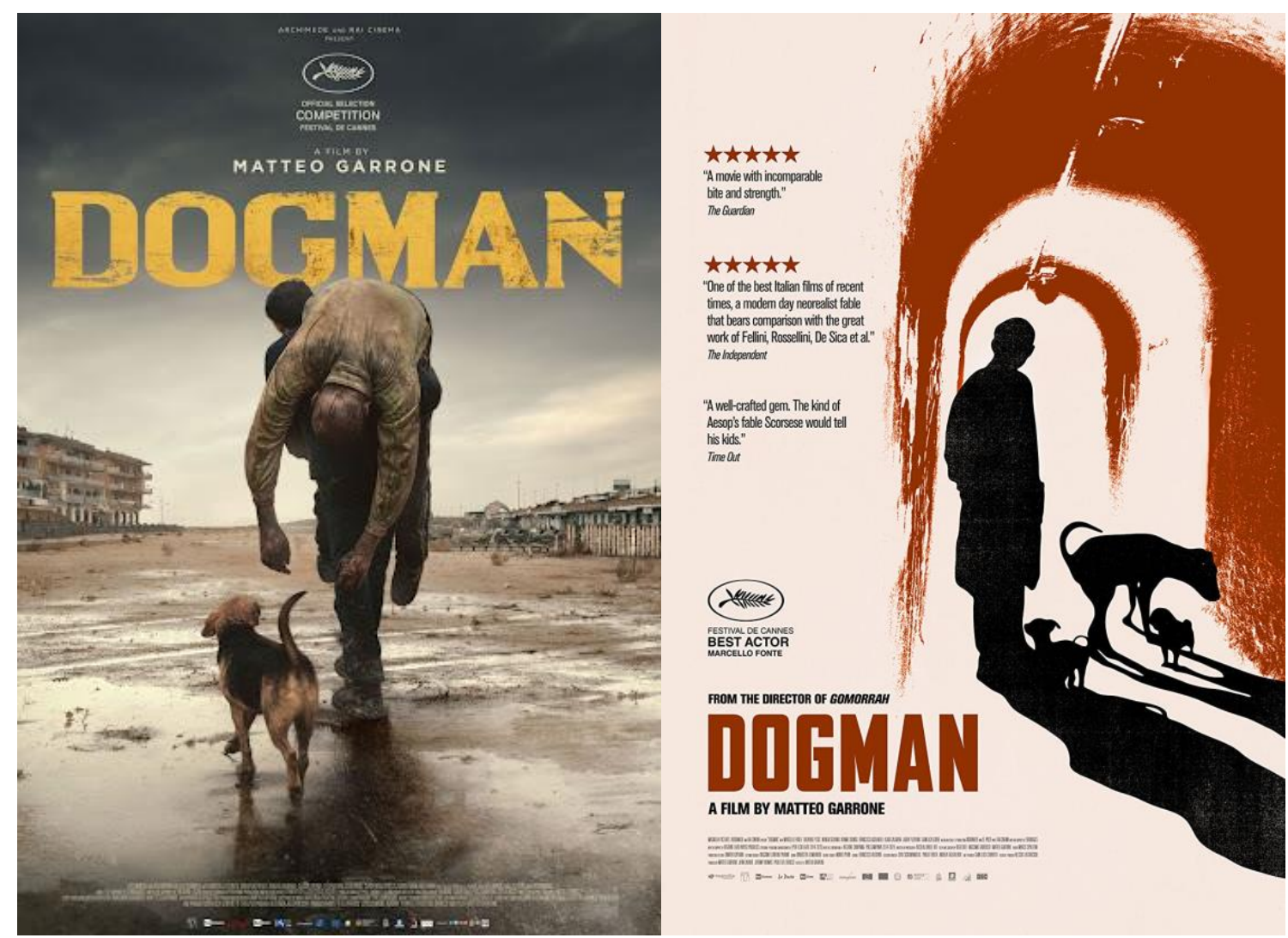

Figure 1 [left]: Dogman. Magnolia Pictures, 2018. The international poster. Figure 2 [right]: The North American poster made by Magnolia Pictures with the support of Ira Deutchman.

Here, we can see how the genre of the film plays a crucial role in the distribution and promotion strategies. Whether Dogman is identified by IMDb with the three catchy keywords "Crime", "Drama", and "Thriller", as stated by Block it is very hard for a foreign language film to reach a younger audience in the US. At the same time, the film brings forward a certain image of Italy that is distant from the traditional imagery of Italianness that was portrayed by the Italian cinema of the past. Even for this reason, thanks to the support of Ira Dutchman's programme, Magnolia decided to increase their advertising budget in a significant way: investing more on targeted Facebook or Instagram social campaigns, creating some podcast advertising, organising 
outdoor advertising in Manhattan too. At the same time, they wanted to recut the original trailer and drastically change the poster of the film. As stated again by Block,

For Dogman, the trailer was good, but it was too dark for our audience, so we needed to totally recut it. The result is similar, because it's the same film, but we softened it a little bit: we made it more about the story of redemption of the main character, rather than just a crime thing. Do you remember the poster where he's walking and carrying a big body over him? We couldn't use that, it was too much. We ended up using a poster that worked like a throwback to traditional old-school arthouse releases: typically those kind of movie posters are a little too narrow focused for the wider audience, but for Dogman we want to hit the old school "foreign cinema fans", for whom that kind of design may appeal. Sometimes you also have to think about the theaters in the US where your posters will be hung. (Qtd. in Garofalo, "Making”)

It is interesting to note how both the recut of the trailer and all the adjustments to the poster have been geared toward a switch in terms of a possible double perception of the film: on the one hand, they wanted to change the idea of an Italian film relating to a specific national canon, and so they tried to present Dogman as a European film as much as possible; on the other hand, they wanted to refer more to the tradition of European arthouse foreign films than to the crime drama genre, and they worked in this direction by creating a new vintage design for the promotion. Even if North American audiences are usually fond of organised-crime movies, indeed, Dogman was not really considered a mobster movie, especially on account of the absence of all the main stereotypes of the genre, or the mafia itself. Nevertheless, the connection with Gomorrah was crucial in the decision of acquiring the distribution rights of Dogman. As Block noted, "we wouldn't have bought Dogman if it wasn't directed by Matteo Garrone, because he is a known quantity and it's an easier sell for us" (qtd. in Garofalo, "Making"). Therefore, on the poster made for the US market we see the reference to Garrone with the caption "From the director of Gomorrah", which is not present in the first version of the poster. Regarding the trailer, we see the same caption at the beginning of it. Here, we can also see how the character of Marcello (Marcello Fonte) is mostly presented in the relation with his daughter, then with his dogs, and finally with Simone (Edoardo Pesce).

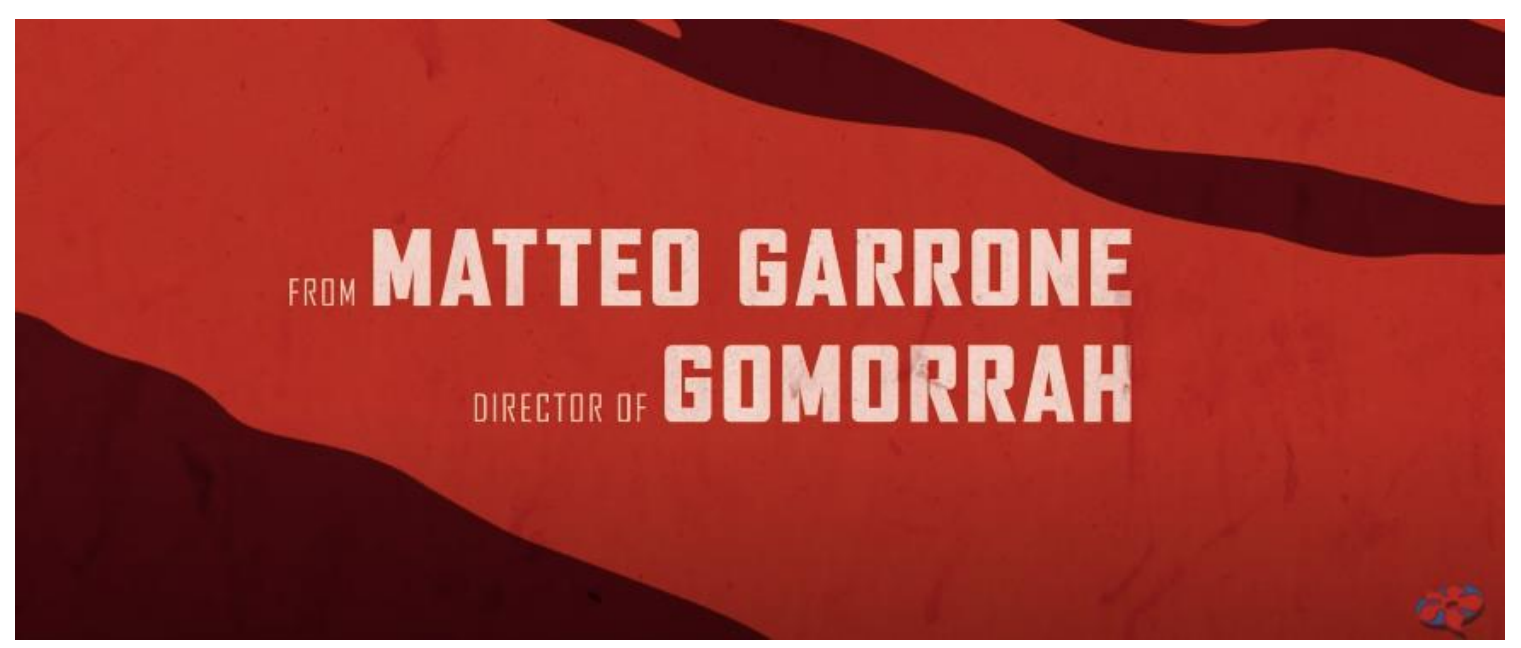

Figure 3: A screenshot from the US trailer of Dogman. Magnolia Pictures, 2018. 
The support of the Cinema made in Italy fund played a decisive role in strengthening all these promotion strategies for the film. Ira Deutchman's work on Italian cinema started via the friendship and collaboration with Roberto Cicutto from Cinecittà Luce. His job is to look at the Italian films that could possibly be released in the United States starting from international film festivals; then, to manage the fund so that these films are able to get a distribution in the US. One of the conditions of Deutchman's involvement is that the distributor has already committed funding in the promotion of the film: therefore, his work acts in an incremental way, not in a substitutional one. In the case of Dogman, after obtaining the confirmation of the involvement of Magnolia in an "aggressive" promotion campaign, he invested part of the funds to buy additional advertising and support, and to make sure that the film got out as broadly as possible (Deutchman qtd. in Garofalo, "Cinema"). At the same time, he managed the Oscar campaign of the film using both the Cinecittà Luce fund and his own resources, organising several additional releases of the film between New York and Los Angeles after the standard distribution. Some other funds were used to reach a younger audience that are not used to watching foreign films or arthouse cinema. As Deutchman himself stated:

What I'm talking about doing with Dogman is spending all my money on electronic media, I'm not doing any newspaper advertising. I just want to try new things, to see if we can find little pockets of audience that we wouldn't have reached otherwise. I'm convinced that we can find a younger audience for these things, younger audiences are more open to subtitles. I was talking with my dad last night, I can't remember which film we were talking about, but the minute he heard it was subtitled he just said "no, I can't watch it with subtitles". Ok, whatever. (Qtd. in Garofalo, "Cinema")

The need to identify a younger audience that might be interested in a film like Dogman results from the desire to open to markets other than those in which Italian auteur cinema traditionally circulates. However, at the time of writing the film was available in streaming for North American audiences just on Hulu, which explains the hesitation of European art cinema promoters to open to the over-the-top global markets and to overcome the dependence on the movie theatre's centrality.

\section{Conclusions}

The analysis of the distribution strategies of the film shows how the case of Dogman follows the trends of theatrical circulation of Italian auteur cinema in the United States. In the same way, the study of the promotion shows all the difficulties of a European film that, even though aiming at a different and renewed target audience, ends up circulating within the niche market of the traditional independent circuits. The film directed by Garrone obtained a decent box-office revenue in the United States if compared to other Italian films, but this pales in front of the consistent results of other national cinemas, which seem to be much better equipped to have their say in markets considered as intermediate between the commercial and the niche ones. Just to make a few examples, we can recall the case of France or of some Asian cinemas, such as the Japanese or Korean ones, which in recent years have experimented, in the wake of the British model, with a typology of exportable film that is more appropriately "middlebrow". Dogman's imagery of reference is still that of European auteur cinema, with a discrete component of realism 
in the mise en scène-even if somewhat complicated by oneiric and visionary elements, which partially distance Garrone from the Italian neorealist tradition (Zagarrio) - and a clearly oppositional character, both in aesthetic and productive terms, towards the commercial markets. Of considerable interest is how the perception of the nationality of the film by stakeholders and professionals does not represent a particular discriminating factor that defines its distribution or promotional life. However, the US distribution immediately tries to sell Dogman as a film that is more European than Italian, both for the impersonal character of the location in which it is shot, and for its partial distancing from a certain type of canon of Italian cinema of the past. It is a canon strongly influenced, at least in the United States, by the success that accompanied the reception of Neorealism in the postwar period, which still represents a critical category of certain fortune and which influenced the large international circulation of Italian auteur cinema of the 1960s. The desire to distance contemporary Italian cinema from these tendencies also appears to be the result of a desire to identify a younger, more globalised target audience, which has practically never had the opportunity to experience that type of films in theatres or elsewhere, and whose reception of European cinema may appear less "filtered" by historical or national canons or tendencies, being now accustomed, thanks to dozens of digital platforms, to the practice of seeing foreign films or series with subtitles. The distance from the canon of Italian cinema, and the critical perception of Dogman as a European film, rather than a proper national one, come also from another factor, which seem to be more linked to the film text rather than the context of reception, distribution and promotion. The fact is that Dogman, as opposed to Gomorrah, is not a mafia movie: it does not depict classical mobsters or gangsters, and there is no trace of organised crime. The story is more intimate, the crime is almost incidental and related to dramatic feelings rather than the stereotypes of the genre. For all these cultural and industrial reasons, we could therefore define Garrone's film more as a European crime drama than a proper and specific Italian film.

\section{Notes}

${ }^{1}$ On the occasion of a research project on the International Circulation of Italian Cinema (PRIN 2015), we collected several data on this topic and published some infographic based on it ("Data").

${ }^{2}$ All the data on audiences, admissions and gross presented here come from: LUMIERE-European Audiovisual Observatory and Box Office Mojo-Amazon Studios; the general data on production and distribution come from: Filmitalia-Cinecittà Luce and IMDb Pro-Amazon Studios.

${ }^{3}$ Here, I matched data coming from LUMIERE (European Audiovisual Observatory) and Box Office Mojo (Amazon Studios).

${ }^{4}$ See, for example, the case of the distribution of Nanni Moretti's films in France (Coladonato and Garofalo).

${ }^{5}$ Here, I matched data coming from Filmitalia (Cinecittà Luce) and IMDb Pro (Amazon Studios). 
${ }^{6}$ All the following information about the distribution of Dogman in the United States come from two conversation I had in March 2019 as part of a research project on the International Circulation of Italian Cinema. The first one is with Neal Block from Magnolia Pictures, whom I met on 19 March 2019 at his office on 49 West 27th Street, New York City; the second is with Ira Deutchman, whom I met on 18 March 2019 at French Roast Cafe on 85th and Broadway, New York City (Garofalo, "Cinema"; "Making"). On both the occasions, I was with my colleagues Marco Cucco, Emiliano Morreale and Massimo Scaglioni, together with whom I conducted the conversations.

\section{References}

Barra, Luca, and Massimo Scaglioni. "Il ruolo della televisione nel sostegno al cinema italiano." Il cinema di Stato. Finanziamento pubblico ed economia simbolica nel cinema italiano contemporaneo, edited by Marco Cucco and Giacomo Manzoli, Il Mulino, 2017, pp. 85125.

Brembilla, Paola. "The Critical Reception of Gomorra Abroad." International Circulation of Italian Cinema, 14 March 2019, www.italiancinema.it/the-critical-reception-of-gomorraabroad.

---. "The International Circulation of Gomorra." International Circulation of Italian Cinema, 20 Feb. 2019, www.italiancinema.it/the-international-circulation-of-gomorra.

Elsaesser, Thomas. European Cinema: Face to Face with Hollywood. Amsterdam UP, 2005.

Call Me by Your Name [Chiamami col tuo nome]. Directed by Luca Guadagnino, Frenesy Film Company, 2017.

Coladonato, Valerio, and Damiano Garofalo. "Nanni Moretti in France: Industrial and Cultural Models of an Italian Auteur's Success Abroad." Incontri. Rivista europea di studi italiani, vol. 33, no. 2, 2018, pp. 102-17.

"Data." International Circulation of Italian Cinema, 2018-2020, www.italiancinema.it/category/data. Accessed 15 Jan. 2022.

Dogman. Directed by Matteo Garrone, Archimede Film/Rai Cinema, 2018

Fadda, Michele, and Damiano Garofalo. "The Distribution of Contemporary Italian Cinema in the United States: The Films of Luca Guadagnino and Paolo Sorrentino." Comunicazioni sociali, vol.40, no. 3, 2018, pp. 369-83. 
Garofalo, Damiano. "Cinema Made in Italy. An Interview With Ira Deutchman.” International Circulation of Italian Cinema, 8 Aug. 2019, www.italiancinema.it/cinema-made-in-italyan-interview-with-ira-deutchman.

---. "Making Italy Marketable. An Interview with Neal Block (Magnolia Pictures)." International Circulation of Italian Cinema, 12 Aug. 2019, www.italiancinema.it/making-italyacceptable-an-interview-with-neal-block-magnolia-pictures.

---. “Global Guadagnino: International Circulation and Critical Reception of Luca Guadagnino's Films." Cinergie, vol. 9, no. 18, 2020, pp. 37-47.

Gomorrah [Gomorra]. Directed by Matteo Garrone, Fandango/Rai Cinema, 2008.

The Great Beauty [La grande bellezza]. Directed by Paolo Sorrentino, Indigo Film, 2013.

Higson, Andrew. "The Concept of National Cinema." Screen, vol. 3, n.4, 1989, pp. 36-47. https://doi.org/10.1093/screen/30.4.36.

---. Waving the Flag. Constructing A National Cinema in Britain. Clarendon Press, 1995.

Holdaway, Dom, and Massimo Scaglioni. "From Distribution to Circulation Studies: Mapping Italian Films Abroad." Comunicazioni sociali, vol. 40, no. 3, pp. 341-55. https://doi.org/10.26350/001200_000024.

I Am Love [Io sono l'amore]. Directed by Luca Guadagnino, First Sun, 2009.

International Circulation of Italian Cinema. Project website, https://www.italiancinema.it/. Accessed 15 Jan. 2022

O’Leary, Alan. "What is Italian Cinema?" California Italian Studies, vol. 7, n.1, 2017. https://doi.org/10.5070/C371029753.

Perren, Alisa. Indie, Inc. Miramax and the Transformation of Hollywood in the 1990's. U of Texas $\mathrm{P}, 2012$.

Reality. Directed by Matteo Garrone, Archimede Film/Fandango, 2012.

Scaglioni, Massimo, ed. Cinema Made in Italy. La circolazione internazionale dell'audiovisivo italiano. Carocci, 2020.

Segrave, Kerry. Foreign Films in America: A History. McFarland, 2004.

Tale of Tales [Il racconto dei racconti]. Directed by Matteo Garrone, Archimede Film, 2015. 
Tudor, Andrew. "The Rise and Fall of the Art (House) Movie." The Sociology of Art: Ways of Seeing, edited by David Inglis and John Hughson, Palgrave Mcmillan, 2005, pp. 125-38.

Youth. Directed by Paolo Sorrentino, Indigo Film, 2015.

Zagarrio, Vito. “Dogman”. Matteo Garrone, edited by Christian Uva, Marsilio, 2020, pp. 127-43.

\section{Suggested Citation}

Garofalo, Damiano. "The Distribution and Promotion of Dogman (2016) in the United States." Alphaville: Journal of Film and Screen Media, no. 22, pp. 54-65. https://doi.org/10.33178/alpha.22.04.

Damiano Garofalo is Assistant Professor at Sapienza University of Rome, where he teaches Cinema History, Television History, TV Serial Narratives, and Audience Research. After having obtained his $\mathrm{PhD}$ in Cultural History at the University of Padova, he worked as a postdoctoral researcher at the Catholic University of Milan, where he was involved in a research project on the international circulation of Italian cinema. Among his research topics are the representation of history in audiovisual media, the relationships between cinema and memory, the cultural and social history of Italian cinema and television, and film distribution and circulation strategies. 